\title{
Lockdowns and reduction of economic activities during the COVID-19 pandemic improved air quality in Alexandria, Egypt
}

\author{
Mostafa M. El-Sheekh (D) I Ibrahim A. Hassan
}

Received: 2 October 2020 / Accepted: 30 November 2020 / Published online: 15 December 2020

(C) The Author(s), under exclusive licence to Springer Nature Switzerland AG part of Springer Nature 2020

\begin{abstract}
Parallel reductions in atmospheric aerosols (particulate matter $(\mathrm{PM})$ ) and nitrogen dioxide $\left(\mathrm{NO}_{2}\right)$ accompanied the drastic measures that were adopted to limit the spread of COVID-19. The results of this preliminary study conducted in northern Egypt revealed that ambient $\mathrm{PM}_{10}, \mathrm{PM}_{2.5}$, and $\mathrm{NO}_{2}$ levels decreased by $22.8 \%, 29.3 \%$, and $25.9 \%$, respectively, after the lockdown started on March 13, 2020. These reductions in concentrations significantly $(p<0.01)$ correlated with the decrease in transportation and industrial and other economic activities. Furthermore, $\mathrm{PM}$ and $\mathrm{NO}_{2}$ concentrations radically reduced during the full lockdown on Easter, Ramadan, and Eid Al-Fitr. The findings of this study will help the World Health Organization (WHO) and other health regulators to combat COVID-19 in the world. This study is part of an ongoing research related to the current pandemic.
\end{abstract}

Keywords Air quality $\cdot$ COVID-19 $\cdot$ Lockdown $\cdot \mathrm{PM}_{10}$. $\mathrm{PM}_{2.5} \cdot \mathrm{NO}_{2}$

M. M. El-Sheekh $(\bowtie)$

Botany Department, Faculty of Science, Tanta University, Tanta 31527, Egypt

e-mail: mostafaelsheikh@science.tanta.edu.eg

I. A. Hassan

Faculty of Science, Alexandria University, Moharem Bay, Alexandria 21511, Egypt

I. A. Hassan

National Scientific Committee of Problems in Environment (SCOPE), Academy of Scientific Research \& Technology, 101 Kas El Ini Street, Cairo, Egypt

\section{Introduction}

The increased population and rapid urban and industrial growth in Egypt have created overcrowded streets filled with cars and trucks, exacerbating air quality (Mostafa et al. 2018). Vehicular emissions and various industrial activities are the principal sources of particulate matter (PM) and $\mathrm{NO}_{2}$, which are harmful to respiratory systems. Both $\mathrm{PM}$ and $\mathrm{NO}_{2}$ are hazardous to human health, as they cause lung damage and asthma (Olivieri and Scoditti 2005).

The World Health Organization (WHO) declared the ongoing global outbreak of COVID-19 as a public health emergency of international concern (World Health Organization 2020a, b), which led to unprecedented public health responses in many countries around the world, including travel restrictions, curfews, and quarantine. The WHO on March 11, 2020, declared COVID-19, the novel coronavirus, as a pandemic (Bashir et al. 2020a; Shi and Brasseur 2020; WHO $2020 \mathrm{a}, \mathrm{b}, \mathrm{c})$ because of its widespread transmission, a significant number of deaths, and higher infections and mortality rate compared to previous coronavirus outbreaks. Shereen et al. (2020) state that it is a singlestranded RNA as nuclei material with a diameter of $\sim 80$ $\mathrm{nm}$. Long-term air quality data significantly correlated with cases of COVID-19 in Italy, giving evidence that chronic exposure to atmospheric contamination represents an encouraging context for the spread of the new virus (Fattorini and Regoli 2020).

The Egyptian government announced that COVID19 had reached the country on February 14, 2020. On 
March 19, 2020, the government implemented some preventive measures by closing all public areas (e.g., restaurants, cafes, clubs, and beauty centers) throughout the country from 7 pm until 6 am, excluding pharmacies and delivery services. Positive COVID-19 cases are increasing daily. On March 22, 2020, governments decided to start social distancing by suspending ritual activities and prayers in all mosques and churches to prevent the spread of COVID-19.

Bauwens et al. (2020) stated that lockdown and reductions in human activities affect the environment positively in China and Western Europe. Similar studies in India (Gupta et al. 2020) and North America (Bashir et al. 2020a, b) support these findings. Although several studies were conducted in North America, Asia, and Europe, no such study was conducted in the Middle East. Therefore, this investigation was conducted in Alexandria City, Egypt, to fulfill the above knowledge gap. This study investigates the impacts of activity reductions and lockdowns, because of COVID-19, on air quality (presented as the concentrations of PM and $\mathrm{NO}_{2}$ ) in Alexandria City, Egypt.

\section{Research methodology}

Air quality sampling

Sequential sampling of $\mathrm{PM}_{10}$ and $\mathrm{PM}_{2.5}$ was conducted using a PartisolTM Plus 2025-D dichotomous sequential air sampler (Thermo Fisher Scientific, USA). The simultaneous sampling of fine and coarse PM is critical for source identification because these particle size fractions often have different origins. The sampler uses the classical US EPA dichotomous virtual impactor design to separate incoming PM air streams into its fine $\left(\mathrm{PM}_{2.5}\right)$ and coarse $\left(\mathrm{PM}_{10}\right)$ components which were collected onto 47-mm Teflon filters for gravimetric analysis (Gelman Teflon, 0.2- $\mu \mathrm{m}$ pore size; Pall Corporation Port Washington, NY) at a rate of $10 \mathrm{~L} / \mathrm{min}(24 \mathrm{~h}$ day $^{-1}$ ). Samples were collected daily from June to May 2020. Teflon filters were weighed before and after sampling using Mettler microbalances (Mettler Toledo® XPR10, Scales Galore, NY, USA) up to an accuracy of $0.001 \mathrm{mg}$ for gravimetric determination of PM (Basahi et al. 2017; Ismail et al. 2017; Harrison et al. 2016a, b). All quartz fiber filters were preheated for $6 \mathrm{~h}$ at $550 \pm 8{ }^{\circ} \mathrm{C}$ and maintained at $20 \pm 1{ }^{\circ} \mathrm{C}$ and relative humidity of $50 \pm 5 \%$ for $24 \mathrm{~h}$ before weighing and sampling. After sampling, all filters were conditioned for $48 \mathrm{~h}$.

$\mathrm{NO}_{2}$ was monitored using a $\mathrm{NO}_{2} / \mathrm{NO} / \mathrm{NO}_{x}$ Monitor (model $405 \mathrm{~nm}$, EQNA-0217-243, 2B Technologies, USA), providing extreme selectivity for $\mathrm{NO}_{2}$ (absorbance at $405 \mathrm{~nm}$ ) over the range $0-500 \mathrm{ppb}$. Concentrations were recorded on the data logger. Both the Partisol air sampler and $\mathrm{NO}_{2}$ monitor were placed on the roof of a residential building in the city center near a busy traffic road in Alexandria City $\left(31^{\circ} 12^{\prime} \mathrm{N} 29^{\circ} 55^{\prime}\right.$ E), $\sim 15 \mathrm{~m}$ above the ground, north of Egypt (Fig. 1). Wind speed and wind directions were collected from the meteorology authority in Egypt (www.ema.gove.eg).

Statistical analyses

The association between COVID-19 and climate indicators (temperature, wind speed, relative humidity, and air quality) in Alexandria City, Egypt, was investigated using Kendall and Spearman rank correlation tests (SPSS statistical package).

\section{Results and discussion}

This study reproduced the evolution of ambient $\mathrm{NO}_{2}$, $\mathrm{PM}_{10}$, and $\mathrm{PM}_{2.5}$ concentrations in Alexandria City, located in northern Egypt, from the beginning of January to the end of May 2020. Figures 2 and 3 show PM and $\mathrm{NO}_{2}$ concentrations, respectively, before and during the coronavirus outbreak, as well as before and during the lockdown. The vertical red line in both figures shows the timing of lockdown and reduction in human activities (March 19, 2020) implemented by the Egyptian government.

The average $\mathrm{PM}_{10}$ concentration was 197 during January, February, and the first 2 weeks in March 2020. This PM10 concentration started to decline after implementing lockdown, and the average concentrations were $\sim 152 \mu \mathrm{g} \mathrm{m}^{-3}$ during April and May. Therefore, the lockdown reduced $\mathrm{PM}_{10}$ concentrations by $22.8 \%$. Moreover, the government implemented drastic measures and a full lockdown during Easter (April 20) and Eid festival (May 23-25, 2020, after the holy month of Ramadan), where $\mathrm{PM}_{10}$ concentrations on these occasions dropped to $121 \mathrm{\mu g} \mathrm{m}^{-3}$ (38.6\% reduction) and $106 \mathrm{\mu g} \mathrm{m}^{-3}$ (46.2\% reductions), respectively (Fig. 2).

Similarly, $\mathrm{PM}_{2.5}$ concentrations were 82 and $58 \mu \mathrm{g}$ $\mathrm{m}^{-3}$ before and during the lockdown, respectively 


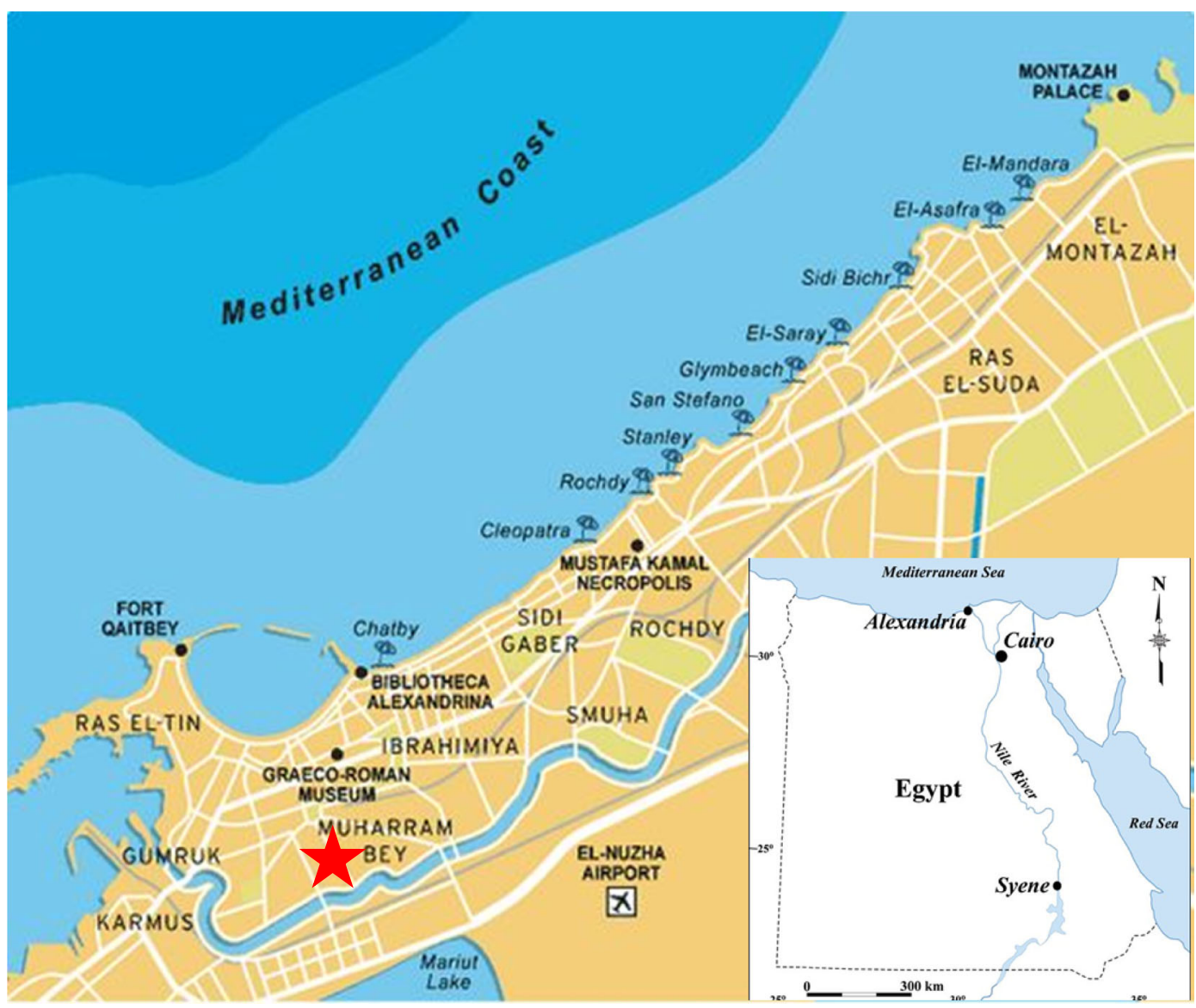

Fig. 1 Map of Alexandria City, Egypt. The location of air quality sampling site is shown by a red star

(lower line in Fig. 2). Moreover, the lowest concentrations were recorded during the full lockdown on April $20\left(44 \mu \mathrm{g} \mathrm{m}^{-3}\right)$ and May 23-25 (40 $\left.\mathrm{g} \mathrm{m}^{-3}\right)$ (Fig. 3). The partial lockdown on March 16, 2020, reduced $\mathrm{PM}_{2.5}$ concentrations by $29.3 \%$, whereas the full lockdown during festivals in April and May reduced the concentration by $46.3 \%$ and almost 1 -fold, respectively. Shi and Brasseur (2020) found that lockdown reduced $\mathrm{PM}_{2.5}$ concentrations by $35 \%$ in northern China.

Fattorini and Regoli (2020) studied the role of chronic air pollution levels in the COVID-19 outbreak risk in Italy. They found that a strong influence of daily
Fig. 2 The mean concentrations of ambient $\mathrm{PM}_{10}$ and $\mathrm{PM}_{2.5}(\mu \mathrm{g}$ $\mathrm{m}^{-3}$ ) in Alexandria City, Egypt, from January 1, 2020, to May 30, 2020. The red vertical line indicates the day (March 13, 2020) during which the lockdown of Egypt was imposed

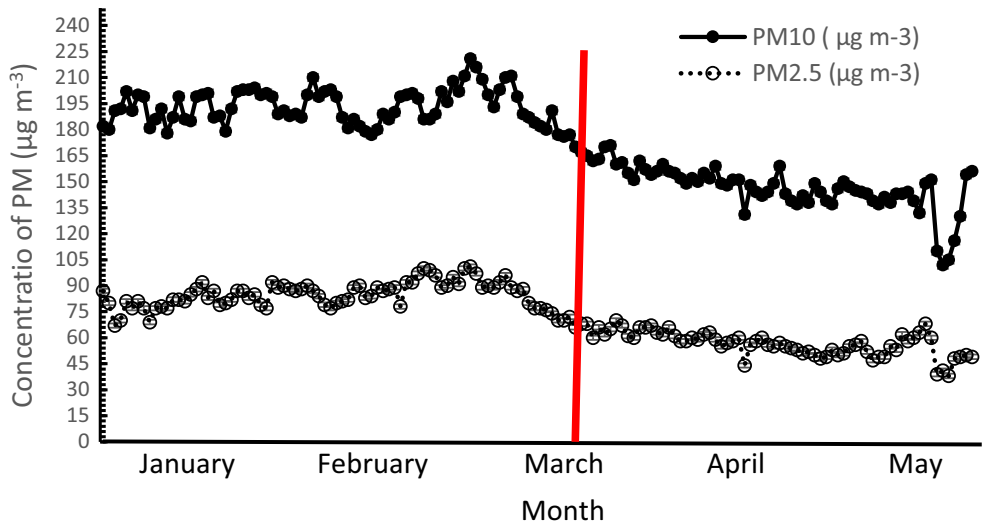




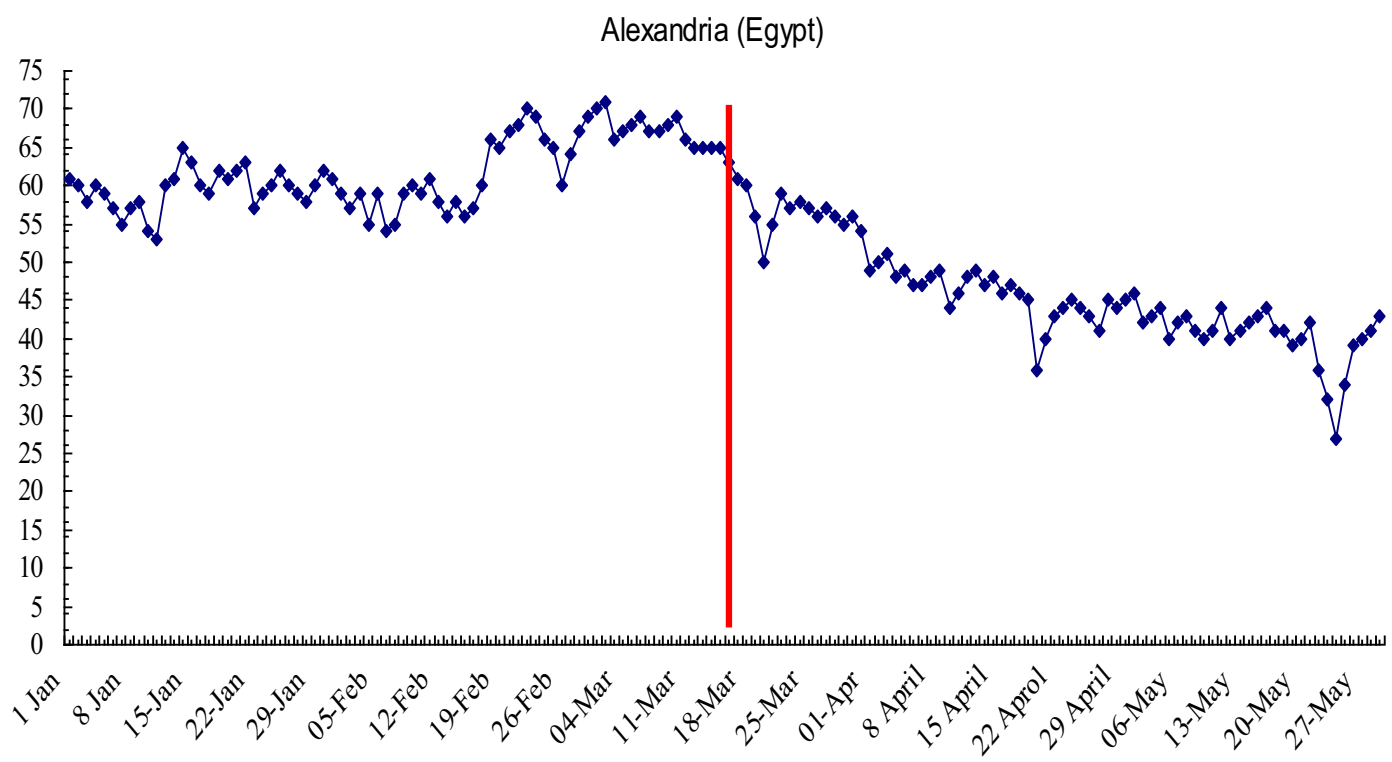

Fig. 3 The mean concentrations of ambient $\mathrm{NO}_{2}\left(\mu \mathrm{g} \mathrm{m}{ }^{-3}\right)$ in Alexandria City, Egypt, from January 1, 2020, to May 30, 2020. The red vertical line indicates the day (March 13, 2020) during which the lockdown of Egypt was imposed

averaged ground levels of PM concentrations was positively associated with average surface air temperature and inversely related to air relative humidity on COVID-19 cases in Milan (Zoran et al. 2020).

$\mathrm{NO}_{2}$ concentrations were 62.5 and $46.3 \mu \mathrm{g} \mathrm{m}$ before and after the lockdown of March 16, 2020, respectively. The lockdown reduced $\mathrm{PM}_{2.5}$ concentrations by $25.9 \%$. Moreover, the $\mathrm{NO}_{2}$ levels recorded during the full lockdown in Easter, and Ramadan and Eid were 35.9 and $30 \mu \mathrm{g} \mathrm{m}^{-3}$, respectively (Fig. 2). The concentrations during the full lockdown were $42.6 \%$ and almost 1-fold lower, respectively, than before lockdown (Fig. 2). Bauwens et al. (2020) stated that ambient $\mathrm{NO}_{2}$ concentrations were reduced by $40 \%, 20 \%$, and $38 \%$ in Wuhan City (China), Western Europe, and the USA, respectively, because of effective lockdown after the outbreak. However, $\mathrm{NO}_{2}$ concentrations in Iran did not decrease because of a delay in lockdown implementation (Bauwens et al. 2020).

Nevertheless, Hassan et al. (2013) found that reductions in $\mathrm{NO}_{2}$ concentrations increased the ambient $\mathrm{O}_{3}$ ozone levels in Jeddah. Recently, Shi and Brasseur (2020) stated that the reduction in ambient $\mathrm{NO}_{2}$ was associated with an increase in tropospheric $\mathrm{O}_{3}$ in China. Although air quality has significantly improved in Egypt, ambient $\mathrm{O}_{3}$ ozone can still be a problem (Zhang et al. 2019). Thus, the relationship between tropospheric $\mathrm{O}_{3}$ and its associated precursors (e.g., $\mathrm{NO}_{2}$ ) warrants further studies. Significant decreases in $\mathrm{NO}_{2}$ levels were observed over widespread areas in China, Europe, South Korea, and the USA in January-April 2020, according to high-resolution spaceborne data.

Figure 4 shows the wind speed and direction. Lockdown significantly affected both meteorological parameters, and consequently, the air quality index significantly improved from that during January and February from the same year (EMA 2020). One could argue that changes in wind speed and wind direction during April and March 2020 could be because of seasonal effects. However, Fig. 5 shows that both parameters for the same site during the same period (April-May) in the previous year (2019) indicate poor air quality, assuring our assumption that lockdown was significant in improving air quality. Zoran et al. (2020) stated that COVID-19 could be attached to airborne aerosols in the infectious agent transmission from a reservoir to a susceptible host in agglomerated urban areas, exacerbating the situation. Moreover, Bauwens et al. (2020) stated that the decrease in $\mathrm{NO}_{2}$ and $\mathrm{PM}$ is evident from the comparison of $\mathrm{NO}_{2}$ levels before and during the lockdown and when contrasting the 2019 and 2020 levels during the same period. The decreases are mainly attributed to the containment measures against the spread of COVID-19, which caused sharp decreases in traffic and industrial activities, correlating well with the results of the recent investigation. 


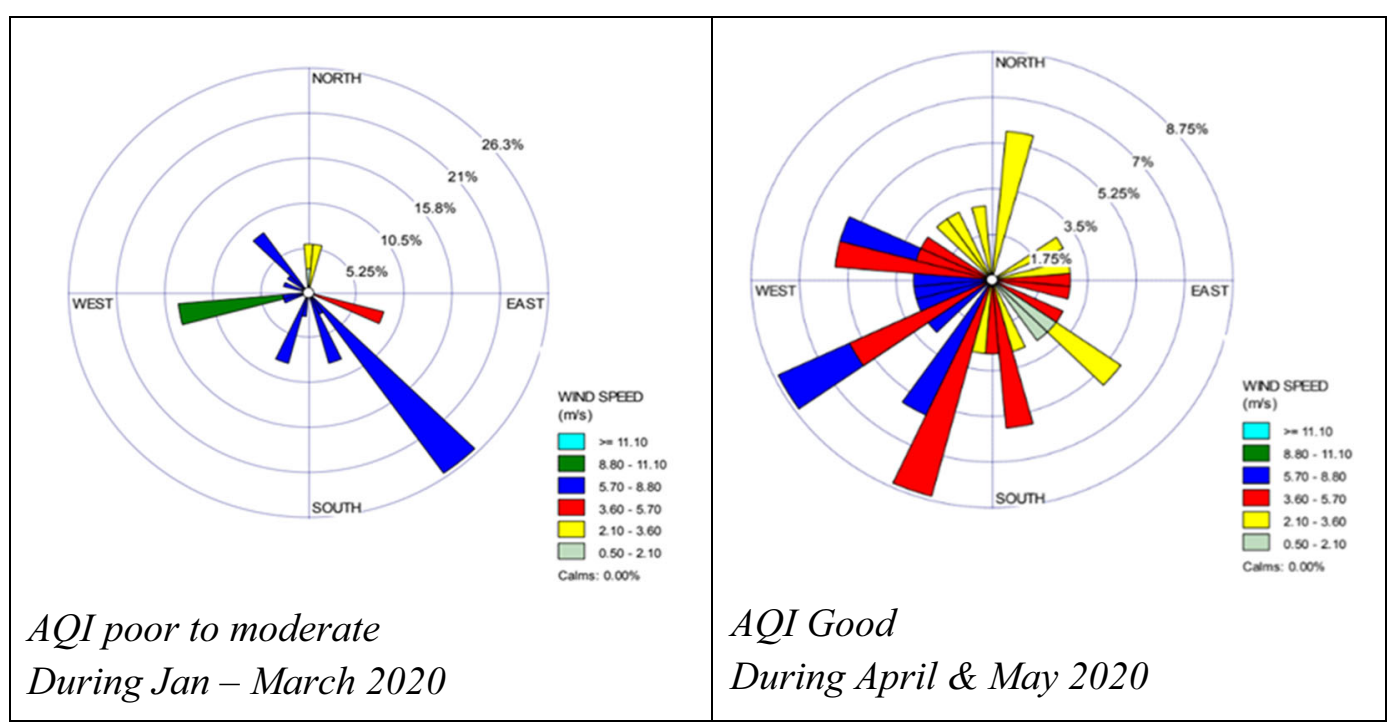

Fig 4 Wind roses in northern Egypt before and during lockdown

The variability in ambient $\mathrm{PM}_{10}, \mathrm{PM}_{2.5}$, and $\mathrm{NO}_{2}$ concentrations with meteorological parameters makes the comparison straightforward in this study. However, an in-depth investigation of the effects of different meteorological parameters during different times a year is urgently needed for a more detailed analysis, which is beyond the scope of this study. Moreover, air pollution should be part of an integrated approach for sustainable development, human health protection, and prevention of epidemic spreads but in a long-term and chronic perspective because adopting mitigation actions during a viral outbreak could be of limited use (Zara 2020; Zoran et al. 2020).
Fig 5 Wind rose in northern Egypt during April-May 2019 (poor air quality)

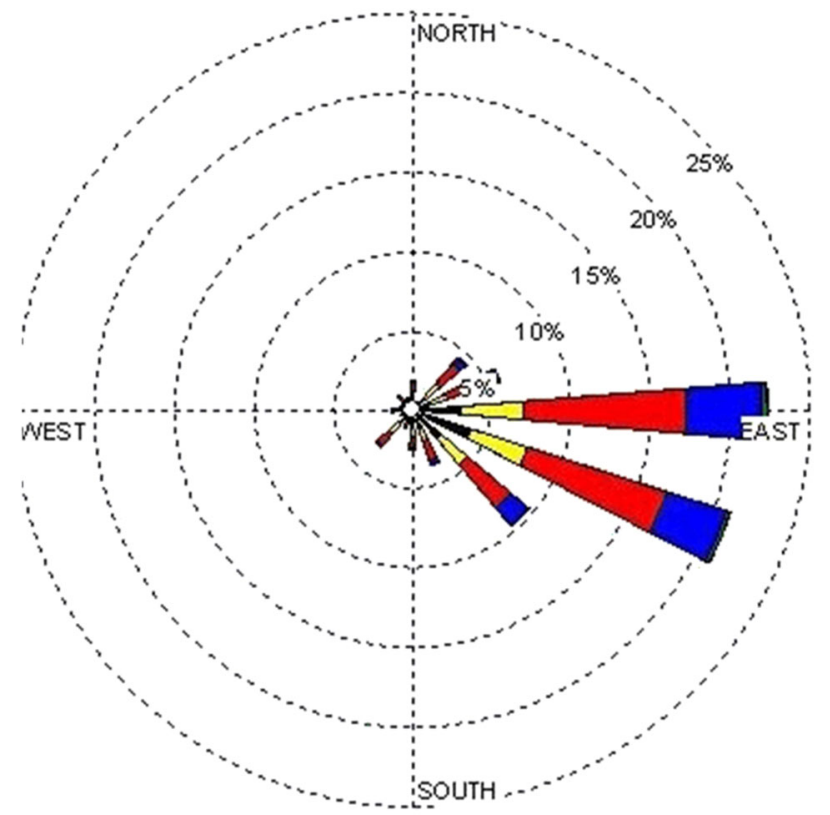

WIND SPEED (Knots)

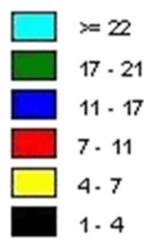

Calms: $18.72 \%$ 
Table 1 Correlation of air quality with air quality parameters with COVID-19 (expressed as no of incidence) and meteorological parameters

\begin{tabular}{|c|c|c|c|c|c|c|c|c|}
\hline Variable & $\mathrm{PM}_{10}$ & $\mathrm{PM}_{2.5}$ & $\mathrm{NO}_{2}$ & Temp. & Wind speed & Relative humidity & No. of cars & No of incidence \\
\hline $\mathrm{PM}_{10}$ & - & 0.57 & 0.44 & 0.50 & 0.64 & 0.51 & 0.57 & 0.68 \\
\hline $\mathrm{PM}_{2.5}$ & & - & 0.47 & 0.49 & 0.50 & 0.65 & 0.62 & 0.71 \\
\hline $\mathrm{NO}_{2}$ & & & - & 0.54 & 0.55 & 0.53 & 0.78 & 0.67 \\
\hline Temperature & & & & - & 0.50 & -0.55 & 0.56 & 0.51 \\
\hline Wind speed & & & & & - & 0.55 & 0.54 & 0.61 \\
\hline Relative humidity & & & & & & - & 0.51 & 0.53 \\
\hline No. of cars & & & & & & & - & 065 \\
\hline No of incidence & & & & & & & & - \\
\hline
\end{tabular}

Italics means significant at $0.01 \leq p<0.05$

A significant correlation exists between air quality and COVID-19 (Table 1). As the number of cars decreased during the lockdown, PM concentrations decreased significantly $(p>0.05)$, and the correlation coefficients were 0.57 and 0.62 for $\mathrm{PM}_{10}$ and $\mathrm{PM}_{2.5}$, respectively (Table 1 ).

The effects of variability of wind direction and speed (e.g., wind gusts) should also be considered. However, our limited dataset did not allow us to investigate these additional variables. Our results contradicted those of Csavina et al. (2014), who found a weak correlation between $\mathrm{PM}_{10}$ and wind speed and relative humidity. However, they found a stronger correlation between $\mathrm{PM}_{10}$ and relative humidity when data were parsed out for high wind speeds but did not observe temperature dependence. Moreover, the dependence of $\mathrm{PM}_{10}$ on wind speed and relative humidity is complex and nonlinear (Csavina et al. 2014).

\section{Conclusions}

The decrease in $\mathrm{PM}$ and $\mathrm{NO}_{2}$ concentrations is mainly attributed to the containment measures against the spread of COVID-19, which caused a sharp decrease in traffic and industrial activities. Emission regulations should be more stringent to improve air quality permanently. However, lockdown and social distancing are not the best solutions to improve air quality and fight COVID-19, although they helped in lowering concentrations of air pollutants significantly, and consequently improved air quality. Moreover, they are temporary solutions; therefore, new innovative and permanent solutions should be suggested, which warrants further investigation. Further studies are needed to evaluate the effects of temporary lockdowns on global air quality and climate and the gradual return to pre-lockdown periods. Lockdowns and social distancing are the best solution to fight COVID-19 but should not be the best technique to improve air quality. Therefore, other solutions should be searched for enhancing air quality. Moreover, model studies are urgently needed to separate the effects of enforced health measures from other contributing factors.

Authors' contributions Mostafa El-Sheekh shared a collection of data and authored and finalized the manuscript. Ibrahim Hassan collected data, authored the manuscript draft, and formulated the tables and figures.

\section{Compliance with ethical standards}

Conflict of interest The authors declare that they have no conflicts of interest.

Ethical approval The manuscript was not submitted to more than one journal for simultaneous consideration. The work is original and not published elsewhere.

\section{References}

Basahi, J., Ismail, I., Hammam, E., \& Hassan, I. (2017). Total suspended particulate matter (TSP) and its associated heavy metals in atmosphere on the Western Coast of Saudi Arabia. Pol J Environ Stud, 26, 2419-2424. https://doi.org/10.15244 /pjoes/69102.

Bashir, M. F., Jiang, M. A., Komal, B. K., Bashir, M. A., Farooq, T. H., Iqbal, N., \& Bashir, M. (2020a). Correlation between environmental pollution indicators and COVID-19 
pandemic: a brief study in Californian context. Environ Res, 187, 109652. https://doi.org/10.1016/j.envres.2020.109652.

Bashir, M. F., Ma, B., Bilal Komal, B., Bashir, M. A., Tan, D., \& Bashir, M. (2020b). Correlation between climate indicators and COVID-19 pandemic in New York, USA. Sci Total Environ, 728, 138835. https://doi.org/10.1016/j. scitotenv.2020.138835.

Bauwens, M., Compernolle, S., Stavrakou, T., Müller, J.-F., Gent, J., Eskes, H., Levelt, P., Veefkind, J., Vlietinck, J., Yu, H., \& Zehner, C. (2020). Impact of coronavirus outbreak on $\mathrm{NO}_{2}$ pollution assessed using TROPOMI and OMI observations. Geophys Res Lett, 47. https://doi.org/10.1029/2020 GL087978.

Csavina, J., Field, J., Félix, O., Corral, A., \& Betterton, E. A. (2014). Effect of wind speed and relative humidity on atmospheric dust concentrations in semi-arid climates. Sci Total Environ, 487, 82-90.

EMA (2020) Egyptian meteorological authority. http://ema.gov. eg/.

Fattorini D, Regoli F (2020) Role of the chronic air pollution levels in the Covid-19 outbreak risk in Italy. Environ Pollut 114732. https://doi.org/10.1016/j.envpol.2020.114732

Gupta, N., Tomar, A., \& Kumar, V. (2020). The effect of COVID19 Lockdown on the air environment in India. Glob $J$ Environ Sci Manag, 6, 31-40.

Harrison, R., Alam, S., Dang, J., Basahi, J., Alghamdi, M., Isamil, I., Hassan, I., \& Khoder, M. (2016a). Influence of petrochemical installations upon PAH concentrations at sites in Western Saudi Arabia. Atmos Pollut Res, 7, 954-960.

Harrison, R., Alam, S., Dang, J., Basahi, J., Alghamdi, M., Isamil, I., Khoder, M., \& Hassan, I. (2016b). Relationship of polycyclic aromatic hydrocarbons with oxy (quinone) and nitro derivatives during air mass transport. Sci Total Environ, 572, 1175-1183.

Hassan, I. A., Bashim, J., Ismail, I., \& Habeebullah, T. (2013). Spatial distribution and temporal variation in ambient ozone and its associated $\mathrm{NO}_{\mathrm{x}}$ in the atmosphere of Jeddah city, Saudi Arabia. Aerosol Air Qual Res, 13, 1712-1722.

Ismail, I. M., Basahi, J. M., Hassan, I. A., Summan, A. S., \& Hammam, E. (2017). Source of heavy metals in aerosol particles in atmosphere of Jeddah City, Saudi Arabia. $J$ Pollut, 1, 111-127.

Mostafa, A. N., Zakey, A. S., Monem, A. S., \& Wahab, M. M. (2018). Analysis of the surface air quality measurements in the greater Cairo (Egypt) metropolitan. Glob J Adv Res, 5, 207-214.

Olivieri, D., \& Scoditti, E. (2005). Impact of environmental factors on lung defenses. Eur Respir Rev, 4, 51-56.

Shereen, M. A., Khan, S., Kazmi, A., Bashir, N., \& Siddique, R. (2020). COVID-19 infection: origin, transmission, and characteristics of human coronaviruses. $J A d v$ Res, 24, 122-129.

Shi X, Brasseur GP (2020) The response in air quality to the reduction of Chinese economic activities during the COVID-19 outbreak. Geophysical Research Letters e2020GL088070. https://doi.org/10.1029/2020GL088070.

World Health Organization (WHO) (2020a) Coronavirus disease (COVID-19) outbreak. https://www.who. int/emergencies/diseases/novel-coronavirus-2019. Accessed 25 April 2020.

World Health Organization (WHO) (2020b) Novel Coronavirus (2019-nCoV), Situation report 1, 21 January 2020, h t t p s : / / w w w. w h o. in t/d o c s/d e fa u $1 \mathrm{t}$ source/coronaviruse/situation-reports/20200121-sitrep-12019-ncov.pdf.

World Health Organization (WHO) (2020c) Novel Coronavirus (2019-nCoV), situation report31, 20 February 2020, h t t p s : / / w w w. who.int/docs / d e fau $1 \mathrm{t}$ source/coronaviruse/situation-reports/20200220-sitrep-31covid-19.pdf. Accessed 25 April 2020

Zara C (2020) Watch flight traffic literally disappear from the skies as the coronavirus hits travel demand. fastcompany. com/90473146/watch-flight-traffic-literally-disappear-fromthe-skies-as-the-coronavirus-hits-travel-demand. Accessed 25 April 2020

Zhang, J., Wei, Y., \& Fang, Z. (2019). Ozone pollution: a major health hazard worldwide. Front Immunol, 10, 2518.

Zoran, M. A., Savastru, R. S., Savastru, D. M., \& Tautan, M. N. (2020). Assessing the relationship between surface levels of PM2.5 and PM10 particulate matter impact on COVID-19 in Milan, Italy. Sci Total Environ, 738, 139825. https://doi. org/10.1016/j.scitotenv.2020.139825.

Publisher's note Springer Nature remains neutral with regard to jurisdictional claims in published maps and institutional affiliations. 